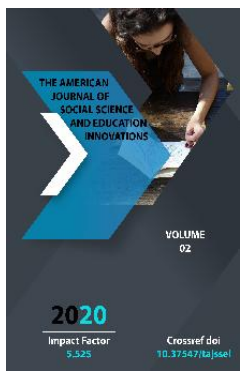

\title{
Civilization, Technosphere And Technical Development As A Legitimate Process
}

\author{
Rustam Samejonovich Amonov \\ Doctoral Student Of The Department Of Philosophy Samarkand State University, Uzbekistan
}

Journal Website:

http://usajournalshub.c

om/index,php/tajssei

Copyright: Original

content from this work

may be used under the

terms of the creative

commons attributes

4.0 licence.

\section{ABSTRACT}

The article considers the transition of society to industrial, industrial civilization, the emergence and content of the Technosphere, the development of technology and its consequences, as a systematic legal process.

\section{KEYWORDS}

Industrial society, industrial civilization, Technosphere, technical development, legal process, technical system, technical and technological object, Information Technology.

\section{INTRODUCTION}

In the process of the cultural development of mankind and the historical development of civilization, the issue of man, his freedom, his right, his well-being, the creation of living conditions worthy of him, the upbringing of a harmonious person and the restoration of a just society have always maintained its relevance, and at the present stage of the development of human civilization, the construction. 
The transition of human society to an economic system based on industrial, industrial civilization, market relations is leading to a surge of modernization processes in all spheres of social life. The development and development of the modern postindustrial or informational civilization is greatly influenced by the processes of globalism. The technological globe, which does not recognize any national boundaries, which represents the occurrence of a common technological and information space in the world, is today manifested as a legitimate process in the development of society, and this new level of quality in the life of society is recognized as an information technical or information - computer civilization.

Today, man and the external world around him are changing as a result of the active technological activities of man. In order to improve human life, to meet its needs, an artificial external environment has been created by mankind, this artificial external environment has been transformed into a system that is connected with mutual internal relations, develops on the basis of its own laws of internal development, into a world that stands above nature, that is, the Technosphere. Today, the influence of the Technosphere on Nature, Society, Culture and the biosphere is growing. At present, attention is paid to the study of the technical phenomenon, its genesis, essence, its role and role in the development of civilization. The role and importance of technology in the life of society, the laws of development, the issues of technical philosophy from the beginning of the $X X$ century to foreign philosophers and sociologists A. Shpengler, $M$. Haydegger, K. Yaspers, F. Dessauera, L. Memford, X. Ortega-i-Gasset, X. Shelsky, J. Friedman, A. Toffler, T. Edoo, D. Bell, X. Lenk,
G. Markuze, L. Memford, F. Rapp, Yu. Habermas, M. Jorgheymer, J. Ellyol, E. Yonger and if studied by others on a scientific basis, then the modern problems of the Technosphere and the philosophical problems of the Technosphere A. M. Burovsky, V. G. Gorshkova, E. S. Demidenko, V. A. Zubakov, V. A. Kutirev, L. V. Leskov, V. L. Inozemtsev, N. N. Moiseev, A. P. Nazaretyan, V. M. Rozin, V. S. Stepin, A.D. Ursul, A. F. Shustov [1] and find their expression in the works of others. The life of a modern person is incomparably covered by technical progress, and in the process of the development of the Technosphere its influence on mankind is increasing. One of the main problems of the philosophy of the Technosphere today is the analysis of the genesis of the technical attitude of man to the world, the role and role of technological rationality and technical activity, the philosophical analysis of the laws of development, the social prediction of the consequences of technical progress, the expression from the study. At present, the state of human influence on the biosphere is also manifested in the situation associated with technical progress.

Technoogen is carried out on the basis of research of legal processes in development, study of the techno-spherical essence in Man and society, analysis of the processes of origin of technoogen objects. The object by which a person surrounds him, and his activities aimed at changing himself, show its impact on the material-economic, spiritual and social spheres of life of society. Artificial material world-the creation of the Technosphere characterizes the technologicalogen legal process in development. The technical creativity of a person gives an opportunity to correctly understand the genesis of the Technosphere. On the basis of the result of human activity, a material culture is created, in which a 
Technosphere is formed. In the process of man's influence on nature, technological objects, technological processes, technical means are created, and also characterize the attitude of the human being to the Technosphere. Humanity influences and transforms the biosphere with the help of technical means to meet its material and socio-economic needs. As a result of the active technological activities of man in many regions of the planet, the biosphere is affected, the biosphere is changed, a new territory of living and functioning for Man is created - the Technosphere. If the biosphere embodies the existing part of life on this earth, then the Technosphere embodies the part of this biosphere that is transformed by people into technical and technological objects, that is, the environment of the population punk.

The relationship between man, society and nature is one of the pressing issues in philosophy. Man is born in nature as a higher being and biological organism with a conscious mind, living in society as a social being, acting in the interests of satisfying his material and spiritual need, having set before him a certain goal. Activity this is the selfexpression of a person's behavior with a certain purpose, an artificial nature is created by a person, which is his own living environment. As a result, certain processes of harmony and originality occur between nature, society and man. The relationship between the biosphere and the Technosphere is also based on the relationship between this nature, society and man. In modern society, cities are growing, industrial centers are established, the living conditions of the people here are changing. At present, many residents of cities live in techno-atmospheric conditions. In the Technosphere, unlike the biosphere, the influence of technological negative factors on a person increases. The impact of transport, industrial enterprises, heat and nuclear power on the environment natural environment - ecology is growing, while the pollution of land, water, air, the use of various chemical substances has a negative impact on the health of people. Technologicalogen accidents in highly industrialized societies also pose risks to the future of nature and humanity. With the complicity and development of technical systems, there have also been changes in the content and essence of the concepts of the technical and technological sphere, if earlier the technique was limited to the sphere of material production, when the technique was equated to the superior level of labor, today the technique covers all the main spheres of life of society, today[2.335]. And the technosphere itself represents the place of residence, which arose as a result of the direct or indirect influence of people and technical means on the natural environment (biosphere) in order to meet social and economic needs. Thanks to the technical development, on the one hand, the unprecedented level of living comfort is becoming more and more difficult for a person to live in a truly human being, on the other hand, under the influence of technical development, he is increasingly away from his social essence and is deprived of most of the spiritual and moral aspects of the traditional [3.259].

The concept of the technosphere has its own structural elements, to which are the technical products and territorial industrial komplexs, the final link of the conversion of natural substances. At the same time, the technosphere as an internal complex structure includes technical works, technical knowledge and technical activity. There are several factors affecting the wide spread of 
the Technosphere in the world, which include the high rate of growth of the population, the level of its urbanization, the increase in consumption of energy resources, the rapid development of industrial and agricultural production, the rapid development in the field of technology, transport, industry, science and technology. Technical development includes technical facilities (equipment, technical equipment, technical equipment, technical system, etc.), as well as technological processes (construction, production of products, operation of equipment, etc.). In the life of society, technical progress is made only on the basis of human activity. As a person lives and works in the Technosphere, he develops techniques, tries to improve his living conditions, affecting nature and changing it.

The Technosphere is also associated with innovation processes. Innovation is becoming the main type of activity in the systems of production and social activity of the present time, expressing the discovery, development and introduction of new ideas, technologies, Information projects and products into society [4.571].

The development of technology today has the potential to have both positive and negative impact on the life of nature and society, and today the creation and functioning of the entire Information Network Internet is a high stage of the achievements of mankind in the field of technology. In practice, informatization is both a technological and social process. Informatization of society is not only a scientific and technical phenomenon, but also a social phenomenon that has arisen as a result of the impact of Science and technology development on society. Therefore, in a broad sense, it is necessary to understand that informatization is an area of importance not only for the economic, but also for the socio-political sphere of production. Informatization as a socio-technological process has its own legislation: the formation of informatization as a leading factor of Social Development, the occurrence of qualitative changes in the social potential of society, the very rapid accumulation of information used in society and the further intensification of this process, the use of information influence of information resources on all spheres of life of the society [5.69].

\section{Conclusion}

Today, great attention is paid to the development of Science and technology, introduction of new technologies, development of telecommunication networks and systems in Uzbekistan. The use of Internet opportunities in production, Education, Science and Culture Development has a positive impact on the development of Science and technology in Uzbekistan.

\section{REFERENCES}

1. https://works.doklad.ru/view/E4/VsxrNnV Y.html.

2. Akhmedova M. Philosophy. Tashkent, National Society of philosophers of Uzbekistan, 2006. -P. 335.

3. Philosophy. Encyclopedic dictionary. Tashkent, National Encyclopedia of Uzbekistan, 2010. -P. 259.

4. Sultanova G.S. Innovative thinking and heuristics // ACADEMICIA: An International Multidisciplinary Research Journal 10 (4), -P. 568-574. 2020.

5. Philosophical-methodological analysis of the modernization process. Tashkent, "Publisher", 2010. -P. 69. 